JURNAL MAKSIPRENEUR, Vol. VII, No. 1, Desember 2017, hal. 59-72

\title{
ANALISIS PENERAPAN BALANCE SCORECARD, ALAT UKUR PENILAIAN KINERJA PADA DINAS PENDAPATAN, PENGELOLAAN KEUANGAN, DAN ASET KABUPATEN SIDOARJO
}

\author{
Mahsina \\ Asmie Poniwatie \\ Cholifah \\ Universitas Bhayangkara Surabaya
}

Korespondensi penulis:mahsina_se@hotmail.com

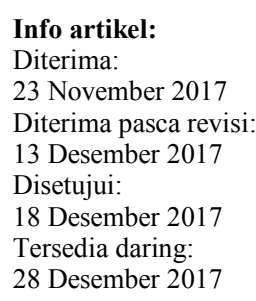

Abstract: Nowadays, the performance measurement is often only measure of financial performance, and it cannot portray overall the company's performance. It's given these shortcomings, then created a performance measurement method that considers the financial aspects as known as the Balanced Scorecard. Balanced Scorecard performance measurement involves four perspectives: i.e. financial perspective, customer perspective, internal business process perspective, and learning and growth perspective. The authors choose to use Dinas Pendapatan, Pengelolaan Keuangan, dan Aset of Sidoarjo Regional Government Agency, because during the measurement of performance of company remains focused on financial aspects. The approach of this study is a qualitative approach. The data source are secondary data, where it is an overview of the company gained from those authorized in the agency, vision, mission, strategy, and corporate organization sectors. The research result of this study using the balanced scorecard performance that involves the four perspectives.

Keywords: Balanced scorecard performance, measurement, financial perspective, Sidoarjo Regional Government.

\section{PENDAHULUAN}

Dewasa ini, perkembangan dunia bisnis mengalami perubahan yang sangat pesat, baik ilmu pengetahuan dan teknologi di bidang informasi, komunikasi, maupun transportasi, serta adanya kebijakan di bidang sosial, politik, dan ekonomi yang secara serentak telah menciptakan kesempatan sekaligus menimbulkan tantangan tersendiri bagi instansi pemerintah memasuki dunia global. Dengan demikian, tidak dapat dipungkiri bahwa suatu instansi dapat bertahan apabila berbasis ilmu pengetahuan dan teknologi dengan didukung sistem pengendalian manajemen yang baik.

Konsep balanced scorecard mulai diperkenalkan pada awal tahun 1990 di Amerika Serikat oleh David P. Norton dan Robert Kaplan melalui suatu riset 
tentang pengukuran kinerja dalam organisasi masa depan. Balanced scorecard terdiri atas dua kata, yaitu balanced (berimbang) dan scorecard (kartu skor). Kata berimbang (balanced) dapat diartikan sebagai kinerja yang diukur secara berimbang dari dua sisi, yaitu sisi keuangan dan non-keuangan. Pengukuran tersebut mencakup rentang waktu jangka pendek dan jangka panjang, serta melibatkan bagian internal dan eksternal. Di sisi lain, pengertian kartu skor (scorecard) adalah suatu kartu yang digunakan untuk mencatat skor hasil kinerja, baik untuk kondisi sekarang atau pun untuk perencanaan di masa yang akan datang guna mencapai tujuan. Pengukuran tersebut perlu menggunakan strategi yang dapat menilai dan mengukur kinerja secara efektif dan komprehensif, sehingga penerapan konsep balanced scorecard sebagai salah satu alternatif yang mampu membantu suatu instansi atau organisasi dalam menentukan strategi pengukurannya. Pada umumnya, pengukuran kinerja pada perusahaan masih menggunakan pengukuran keuangan atau financial perspective (Singgih et al., 2001: 48).

Dengan hanya mengukur aspek keuangan saja, sebuah lembaga pemerintah seperti Dinas Pendapatan, Pengelolaan Keuangan, dan Aset Pemerintah Kabupaten Sidoarjo tidak akan mengetahui seberapa besar pengaruh aspek nonkeuangan, sedangkan aspek tersebut sangat berpengaruh pada efektifitas dan produktifitas perusahaan. Oleh karena itu, Dinas Pendapatan, Pengelolaan Keuangan, dan Aset Pemerintah Kabuapten Sidoarjo perlu menerapkan balanced scorecard agar dapat menilai kinerja secara lebih komprehensif, tidak hanya dari aspek keuangan saja, tetapi dari berbagai perspektif yang ada dalam balanced scorecard agar manajer dan karyawan lebih termotivasi untuk meningkatkan kinerjanya. Berdasarkan latar belakang tersebut, penelitian ini merumuskan permasalahan mengenai bagaimana penerapan balanced scorecard sebagai alat ukur kinerja pada Dinas Pendapatan, Pengelolaan Keuangan, dan Aset di Kabupaten Sidoarjo.

\section{TINJAUAN TEORITIS}

\section{Pengertian Kinerja}

Penilaian kinerja merupakan hal esensial bagi perusahan (Ciptani, 2000: 21). Definisi kinerja menurut Wirawan (2009: 5) adalah keluaran yang dihasilkan oleh fungsi-fungsi atau indikator-indikator suatu pekerjaan atau profesi dalam waktu tertentu. Di sisi lain, kinerja menurut Bastian (2005: 274) adalah gambaran pencapaian pelaksanaan suatu kegiatan/program/kebijakan dalam mewujudkan sasaran, tujuan, misi, dan visi organisasi. Secara umum, kinerja merupakan prestasi yang dicapai oleh organisasi dalam periode tertentu." Menurut Moeheriono (2009: 60), kinerja merupakan gambaran mengenai tingkat pencapaian pelaksanaan suatu program kegiatan atau kebijakan dalam mewujudkan sasaran, tujuan, visi,dan misi organisasi yang dituangkan melalui perencanaan strategis suatu organisasi.

\section{Pengukuran Kinerja}

Menurut Mulyadi (2001: 415), pengukuran kinerja adalah penentuan secara periodik efektivitas operasioanal suatu organisasi, bagian organisasi, dan karyawan berdasarkan sasaran, standar dan kriteria yang telah ditetapakan sebelumnya. Dally (2010: 56) mendefinisikan pengukuran kinerja sebagai tindakan peng- 
ukuran yang dilakukan terhadap berbagai aktivitas dalam rantai nilai yang ada dalam perusahaan, sedangkan Poureisa et al. (2003: 974) menyatakan bahwa:

In traditional performance measurement approach, the most important goals of evaluation is performance measurement while modern approach has focused on evaluated growth and development capacity."

Pentingnya pengukuran kinerja dalam manajemen perusahaan ini, juga ditekankan oleh Zizlavsky (2014: 211) yaitu:

The old adage says: You can not manage what you don't measure.

This is especially true for innovations, where it is absolutely necessary to bring focus, intelligibility and discipline, particularly to the initial, inventive phase of the innovative process. Innovation is a continuous process.

Beberapa literatur menyebutkan bahwa tujuan pengukuran kinerja tidak hanya untuk melihat bagaimana kinerja suatu perusahaan berjalan, tetapi juga dapat membuat perusahaan tersebut memiliki kinerja yang lebih baik, seperti yang dikatakan oleh Kairu et al. (2013: 81) bahwa:

The purpose of measuring performance is not only to know how a

business is performing, but also to enable it to perform better.

Pendapat ini menunjukkan bahwa tujuan pengukuran kinerja tidak hanya untuk mengetahui bagaimana kinerja bisnis, tetapi juga menjadikan bisnis itu mampu memiliki kinerja lebih baik.

\section{Tujuan Pengukuran Kinerja}

Secara umum, tujuan pengukuran kinerja sektor publik adalah sebagai berikut (Halim, 2003: 208):

a. Untuk menghasilkan informasi yang akurat dan valid berhubungan dengan perilaku dan kinerja organisasi atau perusahaan.

b. Mengkomunikasikan strategi secara lebih mantap.

c. Mengelola operasi organisasi secara efektif dan efisien melalui pemotivasian karyawan secara maksimum.

d. Mengidentifikasi kebutuhan pelatihan dan pengembangan karyawan dan menyediakan kriteria seleksi dan evaluasi program pelatihan karyawan.

\section{Konsep Pengukuran Kinerja Tradisional}

Konsep pengukuran tradisioanal sering digunakan perusahaan karena mudah dalam melakukan penilaiannya. Menurut Mulyadi dan Setiawan (1999), ukuran keuangan tidak dapat menggambarkan kondisi riil perusahaan di masa lalu dan tidak mampu menuntun sepenuhnya perusahaan ke arah yang lebih baik, serta hanya berorientasi jangka pendek. Lebih jauh, sistem pengukuran tradisional yang digunakan selama ini kurang menyediakan informasi yang dibutuhkan untuk mengukur dan mengelolah semua kompetensi yang memicu keunggulan kompetitif organisasi bisnis (Giri, 1998). Pengukuran kinerja yang menitikberatkan pada sektor keuangan saja kurang mampu mengukur kinerja harta tak tampak (intangible assets) dan harta intelektual (sumber daya manusia) perusahaan (Hanuman \& Kiswara, 2011: 3). 


\section{Visi, Misi, dan Strategi}

Menurut Wibisono (2006: 43). visi adalah suatu pernyataan tentang gambaran keadaan dan karakteristik yang ingin dicapai oleh suatu organisasi pada masa yang akan datang. Drucker (2000:87) menyatakan bahwa misi adalah pernyataan apa yang harus dikerjakan oleh lembaga dalam usahanya untuk memberikan petunjuk garis besar cara pencapaian visi. Saujana (2000: 1) menerangkan bahwa visi tidak dapat dituliskan secara lebih jelas untuk menerangkan rincian gambarannya, sedangkan misi merupakan pernyataan tentang apa yang harus dikerjakan oleh lembaga dalam usahanya mewujudkan visi. Misi perusahaan adalah tujuan dan alasan mengapa perusahaan itu ada. Misi juga akan memberikan arah sekaligus batasan proses pencapaian tujuan (Saujana, 2000: 1).

Menurut Lynch (2006: 50-51), strategi merupakan pola atau rencana perusahaan yang berkaitan dengan prinsip-prinsip secara umum untuk mencapai misi yang dicanangkan perusahaan, serta bagaimana perusahaan memilih jalur yang spesifik untuk mencapai misi tersebut. Balance scorecard (BSC) lebih mampu menjabarkan visi organisasi ke dalam tujuan-tujuan dan sasaran-sasaran strategis yang saling kait mengait menuju ke pencapaian visi dan misi organisasi (Irsutami \& Ramadhani, 2011: 13).

\section{Balanced Scorecard}

Menurut Sumarsan (2010: 219), BSC adalah sebuah perencanaan strategi dan sistem manajemen yang digunakan secara luas, baik di dalam organisasi yang berorientasi laba maupun nirlaba di seluruh dunia dalam kegiatan-kegiatan usahanya untuk menyelaraskan visi dan strategi organisasi, meningkatkan komunikasi internal dan eksternal, dan mengawasi kinerja organisasi sesuai dengan tujuan strategik perusahaan. Kaplan dan Norton (2000: 7) menyatakan bahwa BSC merupakan suatu metode penilaian yang mencakup empat perspektif untuk mengukur kinerja perusahaan, yaitu perspektif keuangan, pelanggan, bisnis internal, dan pembelajaran dan pertumbuhan. Khaton dan Farouq (2014: 112) menyimpulkan bahwa:

The balanced scorecard is both a performance measurement and management tool that enables the organizations to clarify their vision and strategy and translate them into achievement. It focuses both the financial and non-financial aspects of a company's strategy and discusses cause and effect relationship that drives business achievement.

BSC menutup lubang yang ada di sebagian besar sistem manajemen, yaitu kurangnya proses sistematis untuk melaksanakan dan memperoleh umpan balik sebuah strategi (Sipayung, 2009: 13). Salah satu sistem pengukuran kinerja yang dapat menggambarkan secara komprehensif adalah BSC, karena sistem tersebut lebih mampu menjabarkan visi organisasi ke dalam tujuan-tujuan dan sasaransasaran strategis yang saling kait mengait menuju pencapaian visi dan misi organisasi (Irsutami \& Ramdhaniah, 2011: 1).

Menurut Mulyadi (2001: 1), konsep BSC adalah sebuah pendekatan terhadap strategi manajemen yang dikembangkan oleh Kaplan dan Norton (1990). Hal tersebut juga disampaikan oleh Giannopoulus et al. (2013: 1) yang menyatakan bahwa: 
The Balanced Scorecard is a strategic performance management system used by many companies in the international business environment.

Pada konsep BSC, tidak hanya aspek keuangan (finance) saja yang menjadi tolok ukur kinerja perusahaan. Tiga aspek pengukuran lain juga diperhitungkan meliputi customer, internal business process, dan learning and growth (Kaplan \& Norton, 2000: 8). Sinha (2006: 73) menyebutkan bahwa:

The aim of the Balanced Scorecard is to direct, help manage, and change in support of the longer-term strategy in order to manage performance.

Bahkan, Binden et al. (2014: 38-44) menyatakan bahwa:

The Balanced Scorecard is used as a measurement tool in order to measure an organization's performance in both public and private sectors to achieve the key business strategies and objectives.

Seperti yang juga disampaikan oleh Awadallah dan Alam (2015: 91-99) yang juga menegaskan bahwa penggunaan BSC lebih pada pengukuran terhadap kinerja, strategi manajemen, dan manajemen proyek. Namun, kritik juga diberikan terkait penerapan BSC yaitu Peck (2004) melakukan observasi bahwa BSC mengubah strategi ke dalam pengukuran kinerja yang tangible. Kemudian, Awadallah dan Alam (2015: 91-99) juga memberikan kritik yang lebih rinci, yaitu BSC tidak mampu mendiskripsikan parameter key performance indicators (KPI).

BSC sangat tepat diaplikasikan pada perusahaan kecil dan menengah (Small and Medium Enterprises) seperti yang dikatakan oleh Suprapto et al, (2009: 7687) bahwa:

The adoption of four BSC components which are learning and growth; mission and vision; customer, and internal business are applicable for non-financial SMEs' performance.

BSC merupakan suatu sistem manajemen strategik atau lebih tepat dinamakan strategic-based responsibility accounting system yang dapat menjabarkan misi dan strategi organisasi ke dalam tujuan operasional dan tolok ukur kinerja organisasi tersebut.

\section{Perspektif dalam Balanced Scorecard}

Kaplan dan Norton (2000: 7) menjelaskan bahwa BSC meliputi empat perspektif yaitu:

\section{Perspektif Keuangan (financial perspective)}

Guinea (2012) menjelaskan apa yang diharapkan oleh penyedia sumber daya terhadap kinerja keuangan keuangan organisasi, yaitu mayarakat pembayar pajak. Secara umum, masyarakat mengharapkan uang yang telah mereka bayarkan dapat digunakan oleh pemerintah secara efesien dan efektif, serta memenuhi prinsip-prinsip transparansi dan akuntabilitas publik. Ada pun konsep indikator kinerja yang ada di dalam perspektif keuangan adalah: (1) Rasio efektivitas pendapatan asli daerah, dan (2) Rasio aktivitas.

2. Perspektif Pelanggan (customer perspective)

Kinerja pada perspektif pelanggan memiliki dampak langsung terhadap meningkatnya penjualan perusahaan (Himawan \& Juarsah, 2005: 82). Tujuan perspektif pelanggan untuk mengetahui bagaimana pelanggan 
melihat organisasi, sedangkan perbedaannya terletak pada siapa yang mennjadi pelanggan (Mahmudi, 2009). Pada organisasi sektor publik, yang menjadi pelanggan utama adalah masyarakat pembayar pajak dan masyarakat penguna layanan publik. Untuk melihat tingkat kepuasan pelanggan, Parasuraman dan Berry (1996) mengembangkan sebuah instru-men yang dinamakan Service Quality (Servqual) yang mengukur kepuasan dari beberapa dimensi, antara lain: (1) Wujud fisik yaitu penampilan fisik seperti: tempat layanan, serta sarana dan prasarana yang dapat dilihat langsung secara fisik oleh pelanggan, dan (2) Keandalan (reliability) yaitu kemampuan untuk memberikan layanan yang dijanjikan dengan tepat waktu dan memuaskan.

3. Perspektif Proses Bisnis Internal (internal business process perspective) Pada dasarnya, perspektif proses bisnis internal adalah membangun keunggulan organisasi melalui perbaikan proses internal organisasi yang berkelanjutan (Mahmudi, 2009). Beberapa aspek yang dapat memberikan gambaran kinerja perspektif ini adalah: (1) Sarana dan Prasarana, dan (2) Proses.

4. Perspektif Pertumbuhan dan Pembelajaran (learning and growth perspective)

Dalam organisasi sektor publik, perspektif pertumbuhan dan pembelajaran difokuskan untuk menjawab pertanyaan bagaimana organisasi terus melakukan perbaikan dan menambah nilai bagi pelanggan dan stakeholdersnya (Mahmudi, 2009). Indikator kinerja yang dapat menggambarkan perspektif ini adalah: (1) Motivasi (rewards and punishment), dan (2) Inovasi.

\section{Keunggulan Balanced Scorecard}

Balanced scorecard memiliki keunggulan yang menjadikan sistem manajemen strategik dalam manajemen tradisional. Keunggulan pendekatan BSC dalam sistem perancanaan strategis adalah menghasilkan rencana strategis (Mulyadi, 2001: 18). Keunggulan BSC memiliki karakteristik sebagai berikut: (a) Komprehensif, (b) Koheren, (c) Seimbang, dan (d) Terukur.

\section{METODE PENELITIAN}

\section{Jenis Penelitian}

Jenis penelitian ini adalah case study. Yin (1989) menjelaskan bahwa:

Case study is an empirical inquiry that investigates a contemporary phenomenon within its real life context when the boundaries between phenomenon and context are not clearly evident and in which multiple source of evidence are used.

Metode lain yang digunakan adalah diskriptif, yaitu data yang dikumpulkan berupa rangkaian kata dan bukan dalam bentuk angka-angka (Moleong, 1996).

\section{Unit Analisis}

Menurut Yin (2009: 30), unit analisis adalah komponen yang secara fundamental berkaitan dengan masalah penentuan apa yang dimaksud dengan kasus dalam penelitian yang bersangkutan. Ada pun unit analisis penelitian ini adalah kinerja Dinas Pendapatan, Pengelolaan Keuangan, dan Aset Kabupaten Sidoarjo. 


\section{Model Analisis}

Model analisis yang digunakan dalam penelitian ini digambarkan pada Gambar 1 berikut ini.

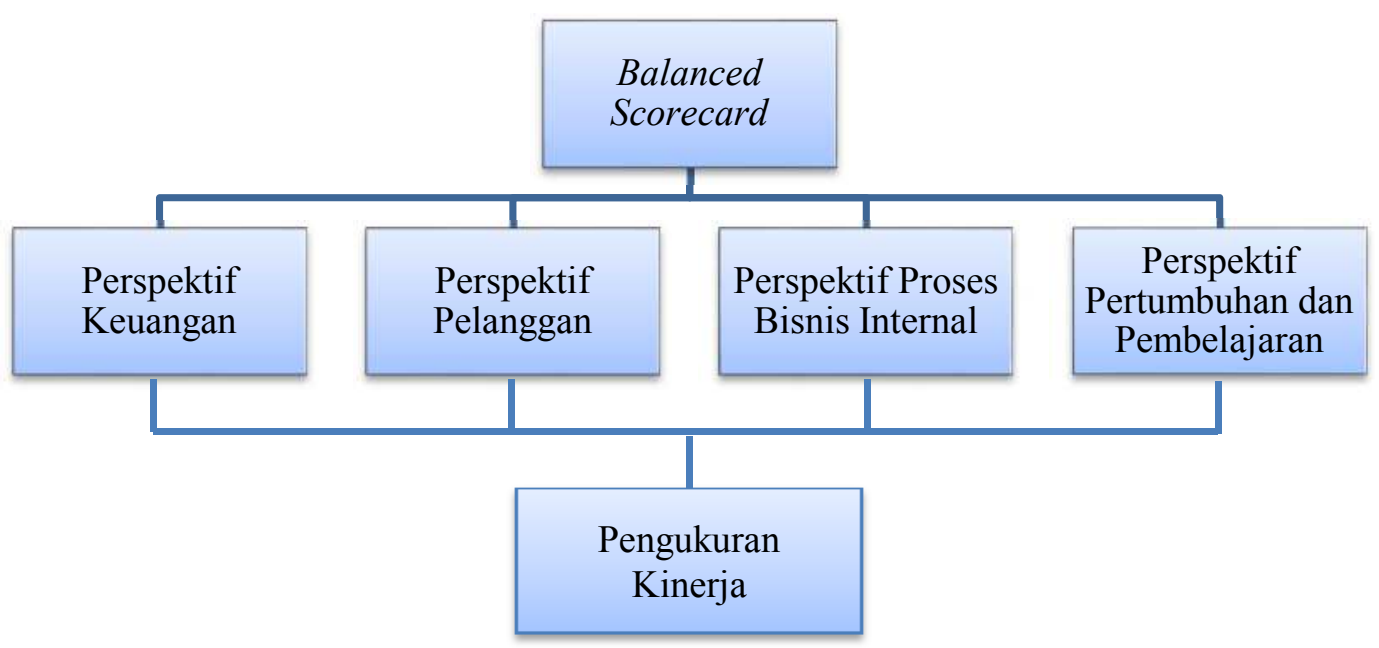

Gambar 1. Bagan Model Analisis

\section{ANALISIS DAN PEMBAHASAN}

\section{Hasil Analisis}

Penelitian ini membahas hasil analisis penerapan BSC sebagai alat ukur penilaian kinerja pada Dinas Pendapatan, Pengelolaan Keuangan, dan Aset Kabupaten Sidoarjo yang memiliki penilaian sangat baik, tetapi organisasi seharusnya mampu mengetahui apakah pengukuran BSC tersebut dapat membantu manajemen dalam pengambilan keputusan supaya bisa mengubah suatu pengukuran kinerjanya yang memerlukan waktu panjang.

2. Identifikasi Program Dinas Pendapatan, Pengelolaan Keuangan, dan Aset

\section{Kabupaten Sidoarjo}

Program-program yang dijalankan oleh Dinas Pendapatan, Pengelolaan Keuangan, dan Aset Kabupaten Sidoarjo adalah: (a) Rencana Program dan Kegiatan Dengan Kerangka Pendanaan, dan (b) Program Pembangunan Rencana Strategis mengacu ketentuan Peraturan Menteri Dalam Negeri Nomor 13 Tahun 2006 tentang Pedoman Pengelolaan Keuangan Daerah yang terakhir telah diubah dengan Permendagri Nomor 59 Tahun 2007, yaitu struktur belanja secara runtut dimulai dari urusan organisasi, belanja tidak langsung (meliputi: jenis, obyek dan rincian obyek belanja) dan belanja langsung (meliputi: jenis, obyek, dan rincian obyek belanja).

3. Hasil Penilaian Kinerja Dinas pendapatan, Pengeloaan Keuangan dan Aset Kabupaten Sidoarjo

\section{a) Perspektif Keuangan}

Rasio Efektivitas (Pendapatan Asli Daerah/PAD)

Ada pun dari rasio efektivitas adalah sebagai berikut:

Dari perhitungan kinerja, rasio efektivitas adalah sebagai berikut:

Rasio Efektivitas $=\frac{\text { Realisasi Penerimaan Pendapatan Asli Daerah (PAD) }}{\text { Target penerimaan PAD yang ditetapkan berdasarkan potensi riil daerah }}$


Tahun 2011

Realisasi Penerimaan Pendapatan Asli Daerah $(\mathrm{PAD})=$ Rp 2.005.191.397.714 (Tabel 1)

Target peneriman PAD yang ditetapkan berdasarkan potensi riil daerah

$=\mathrm{Rp}$ 1.905.993.882.859 (Laporan Realisasi Anggaran)

$\begin{aligned} \text { Rasio Efektivitas } & =\frac{\mathrm{Rp} 2.005 .191 .397 .714}{\mathrm{Rp} 1.905 .993 .882 .859} \\ & =1,0520 \\ & =105,20 \%\end{aligned}$

Rasio efektivitas pandapatan asli daerah pada tahun 2011 adalah 105,20\%.

Tahun 2012

Realisasi Penerimaan Pendapatan Asli Daerah $(\mathrm{PAD})=\mathrm{Rp}$ 2.349.729.13.668 (dalam Laporan Realisasi Anggaran)

Target peneriman PAD yang ditetapkan berdasarkan potensi riil daerah

$=\operatorname{Rp} 2.284 .511 .936 .806$ (dalam laporan Realisasi Anggaran)

$\begin{aligned} \text { Rasio Efektivitas } & =\frac{\operatorname{Rp} 2.349 .729 .138 .668}{\operatorname{Rp} 2.284 .511 .936 .806} \\ & =1,0285 \\ & =\quad 102,85 \%\end{aligned}$

Rasio efektivitas pandapatan asli daerah pada tahun 2012 adalah 102,85\%.

Tabel 1. Rasio Efektivitas Pendapatan Asli Daerah

\begin{tabular}{cc}
\hline Tahun & Rasio Efektivitas Pendapatan Asli Daerah \\
\hline 2011 & $105,20 \%$ \\
\hline 2012 & $102,85 \%$ \\
\hline
\end{tabular}

Sumber: Data diolah (2013).

Dari tabel di atas diketahui bahwa pada Rasio Efektivitas Pendapatan Asli Daerah dari tahun 2011 ke tahun 2012 mengalami penurunan dari $105,20 \%$ menjadi $102,85 \%$.

Rasio Aktivitas

Ada pun perhitungan rasio aktivitas menggunakan perhitungan berikut:

1.

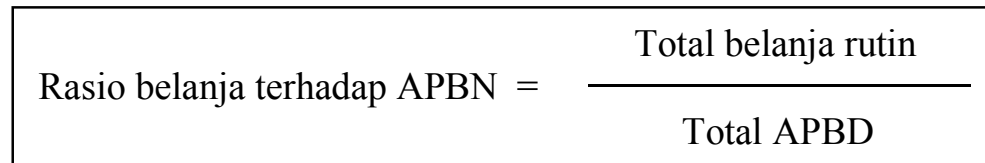

2.
Rasio belanja pembangunan terhadap APBN =
Total belanja pembangunan
Total APBD 
Ada pun perhitungannya adalah sebagai berikut:

Tahun 2011

1. Rasio belanja terhadap APBN

Total belanja rutin

$=\quad \operatorname{Rp} 926.929 .625 .425$

Total APBD

$=\quad \operatorname{Rp} 2.093 .437 .864 .285$

$\begin{aligned} \text { Rasio belanja terhadap APBN } & =\frac{\mathrm{Rp} 926.929 .625 .425}{\mathrm{Rp} 2.093 .437 .864 .285} \\ & =\quad 0,4425 \\ & =\quad 44,25 \%\end{aligned}$

2. Rasio belanja pembangunan terhadap APBN

Total belanja pembangunan $=\quad$ RP 1.259.885.171.556

Total APBD $=\quad \operatorname{Rp} 2.093 .437 .864 .285$

$\begin{aligned} & \text { Rasio belanja pembangunan } \\ & \text { terhadap APBN }\end{aligned}=\frac{\mathrm{RP} 1.259 .885 .171 .556}{\mathrm{Rp} 2.093 .437 .864 .285}$

$=0,6082$

$=60,82 \%$

Tahun 2012

1. Rasio belanja terhadap APBN

Total belanja rutin

Total APBD

$=\quad \operatorname{Rp~1.103.333.525.036~}$

$=\quad \operatorname{Rp} 2.565 .342 .909 .483$

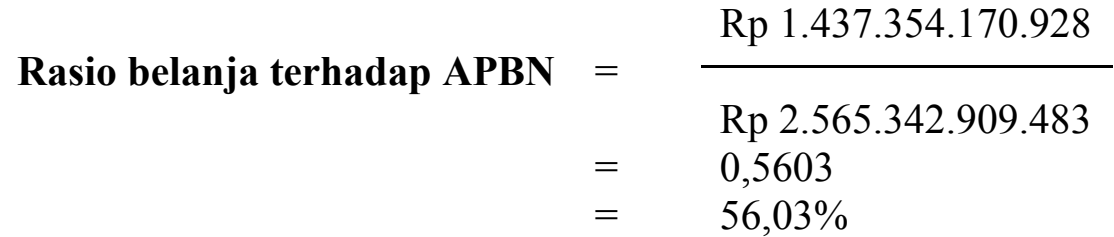

2. Rasio belanja pembangunan terhadap APBN

Total belanja pembangunan $\quad=\quad \operatorname{Rp} 26.689 .328 .497$

Total APBD

$=\quad \operatorname{Rp} 32.561 .060 .064$

$\begin{array}{lll}\begin{array}{l}\text { Rasio belanja pembangunan } \\ \text { terhadap APBN }\end{array} & =\frac{\mathrm{Rp} 26.689 .328 .497}{\mathrm{Rp} 32.561 .060 .064} \\ & =0,8196 \\ & =81,96 \%\end{array}$


Tabel 2. Rasio Aktivitas

\begin{tabular}{ccc}
\hline Tahun & Rasio belanja terhadap APBN & $\begin{array}{c}\text { Rasio belanja pembangunan } \\
\text { terhadap APBN }\end{array}$ \\
\hline 2011 & $44,25 \%$ & $60,82 \%$ \\
\hline 2012 & $56,03 \%$ & $81,96 \%$ \\
\hline
\end{tabular}

Sumber: Data diolahan Peneliti, 2013

Dari Tabel 2 tersebut di atas dapat diketahui bahwa pada tahun 2011, rasio belanja terhadap APBN sebesar 44,25\% dan rasio belanja pembangunan terhadap APBN sebesar 60,82\%. Pada tahun 2012, rasio belanja terhadap APBN sebesar 56,03\% dan rasio belanja pembangunan terhadap APBN sebesar $81,96 \%$.

\section{b) Perspektif Pelanggan}

\section{1) Wujud Fisik (tangibles)}

Wujud Fisik (tangibles) adalah penampilan fisik seperti: tempat layanan, sarana, dan prasarana yang dapat dilihat langsung secara fisik oleh pelanggan. Pemerintah daerah melalui Dinas Pendapatan, Pengelolaan Keuangan, dan Aset Kabupaten Sidoarjo mengembangkan depo-depo untuk membayar pajak.

\section{2) Keandalan (reliability)}

Keandalan (reliability) yaitu kemampuan untuk memberikan layanan yang dijanjikan dengan tapat waktu dan memuaskan. Program-program yang dijalankan oleh Dinas Pendapatan, Pengelolaan Keuangan, dan Aset Kabupaten Sidoarjo, yaitu:

1. Program Pelayanan Administrasi Perkantoran

Program ini bertujuan memberikan dukungan terhadap kelancaran serta keberhasilan dalam layanan administrasi perkantoran.

2. Program Peningkatan Sarana dan Prasarana Aparatur

Merencanakan pengadaan dan kenaikan fungsi sarana dan prasarana pendukung.

3. Program Peningkatan Disiplin Aparatur

Program ini bertujuan meningkatkan disiplin aparatur dalam melaksanakan pekerjaan dalam ruang lingkup tugas pokok dan fungsi.

4. Program Peningkatan Kapasitas Sumber Daya Aparatur

Program ini bertujuan untuk meningkatkan kapasitas sumber daya manusia di lingkungan Satuan Kerja Perangkat Daerah (SKPD) Dinas Pendapatan, Pengelolaan Keuangan, dan Aset dalam segala aspek yang berkaitan dengan pelaksanakan tugas dan tanggung jawabnya.

5. Program Peningkatan Pengembangan Sistem Pelaporan Capaian Kinerja dan Keuangan

Program ini bertujuan untuk memudahkan dalam pelaporan capaian kinerja keuangan.

6. Program Peningkatan dan Pengembangan Pengelolaan Keuangan Daerah

Program ini bertujuan untuk pengelolaan keuangan yang sudah ditentukan. 


\section{c) Proses Bisnis Internal}

\section{Sarana dan Prasarana}

Sarana dan prasarana adalah variabel yang menggambarkan kondisi infrastruktur yang dimiliki dalam mendukung kegiatan internal organisasi. Sarana dan prasarana yang dimiliki oleh Dinas Pendapatan, Pengelolaan Keuangan, dan Aset Kabupaten Sidoarjo antara lain:

i. Rumah Dinas

Rumah dinas ditempati untuk Kepala Dinas dan pegawai Dinas Pendapatan, Pengelolaan Keuangan, dan Aset Kabupaten Sidoarjo.

ii. Kantor

Kantor Dinas Pendapatan, Pengelolaan Keuangan, dan Aset digunakan untuk melakukan kegiatan pendapatan, pengelolaan keuangan, dan aset.

iii. Mendirikan depo-depo di luar area, seperti: mal dan samsat.

\section{Proses}

Proses dimaksudkan untuk mengetahui tingkat kemampuan pegawai atas suatu rangkaian pekerjaan yang dilakukan dalam memberikan layanan publik. Kemampuan pegawai atas suatu rangkaian pekerjaan yang dilakukan dalam memberikan layanan kepada masyarakat antara lain:

i. Mengoptimalisasi tenaga kerja fungsional yang ada.

ii. Memperbarui kualitas sumber daya manusia terkait dengan arah strategis Dinas Pendapatan, Pengelolaan Keuangan, dan Asset Kabupaten Sidoarjo yang telah ditetapkan dalam rangka memudahkan dalam perwujudan visi.

iii. Penyusunan sistem informasi data yang dapat memberikan gambaran nyata pada tingkat lapangan dengan akurasi data dan keterbaruan data yang dapat dipertanggungjawabkan.

\section{d) Perspektif Pertumbuhan dan Pembelajaran}

1. Motivasi (rewards and punishment)

Motivasi (rewards and punishment) menggunakan tingkat kepuasan pegawai atas kebijakan-kebijakan yang diambil manajemen dalam menjalankan organisasi. Inisiatif-inisiatif strategi atau kebijakan umum dalam perspektif ini di antaranya adalah peningkatan kompetensi dan produktifitas sumber daya manusia aparatur, budaya yang transparan dan akuntabel, serta dukungan sarana dan prasarana fisik maupun nonfisik yang memadai.

\section{Inovasi}

Inovasi dalam proses penciptaan nilai tambah bagi pelanggan merupakan salah satu proses kritikal, yaitu efisiensi, efektifitas, dan ketepatan waktu dari proses inovasi ini akan mendorong terjadinya efisiensi biaya pada proses penciptakaan nilai bagi pelanggan.

i. Meningkatkan infrastruktur pendukung pelaksanaan tugas antara lain penyesuaian Peraturan Daerah, Peraturan Bupati, Pedoman Umum, serta sistem dan prosedur tentang pajak dan retribusi daerah. 
ii. Meningkatkan kualitas dan profesionalisme personal Dinas Pendapatan, Pengelolaan Keuangan, dan Aset.

iii. Meningkatkan sarana dan prasarana yang representatif dalam rangka memberikan layanan.

iv. Deregulasi dan debirokratisasi dalam bidang pelayanan perijinan.

\section{KESIMPULAN DAN SARAN}

\section{Kesimpulan} bahwa:

Berdasarkan hasil analisis data yang telah dilakukan dapat disimpulkan

a) Berdasarkan perspektif keuangan kinerja Dinas Pendapatan, Pengelolaan Keuangan, dan Aset Kabupaten Sidoarjo dengan menggunakan rasio efektifitas pada tahun 2011 mengalami penurunan pada tahun 2012, sedangkan rasio aktivitas belanja rutin pada tahun 2011 mengalami kenaikan pada tahun 2012 dan rasio aktivitas belanja pembangunan pada tahun 2011 juga mengalami kenaikan pada tahun 2012.

b) Berdasarkan perspektif pelanggan, Pemerintah Daerah melalui Dinas Pendapatan, Pengelolaan Keuangan, dan Aset Kabupaten Sidoarjo sudah mampu mengoptimalkan layanan untuk membantu masyarakat dan memberikan layanan melalui program-program pioritas pembangunan yang dijalankan oleh Dinas Pendapatan, Pengelolaan Keuangan, dan Aset, yaitu membangun depo-depo pembayaran pajak.

c) Berdasarkan perspektif proses bisnis internal, kemampuan organisasi untuk meningkatkan kualitas layanan kepada pelanggan secara efektif dan tepat waktu, serta meningkatkan kemampuan organisasi supaya bisa menciptakan kepercayaan.

d) Berdasarkan perspektif pertumbuhan dan pembelajaran, Dinas Pendapatan, Pengelolaan Keuangan, dan Aset Kabupaten Sidoarjo telah menjalankan proses operasionalnya sesuai dengan prosedur yang telah ditetapkan Peme-

2. Saran rintah Kabupaten Sidoarjo.

Berdasarkan kesimpulan tersebut di atas, maka saran yang diberikan dari hasil penelitian ini adalah:

a) Dinas Pendapatan, Pengelolaan Keuangan, dan Aset Kabupaten Sidoarjo sebaiknya menerapkan sistem penilaian kinerja dengan menggunakan Balanced Scorecard yang meliputi empat perspektif, yaitu perspektif keuangan, pelanggan, proses bisnis internal, serta pembelajaran dan pertumbuhan.

b) Penilaian kinerja yang dimiliki oleh Dinas Pendapatan, Pengelolaan Keuangan, dan Aset Kabupaten Sidoarjo hendaknya diawasi secara aktual dan terperinci.

\section{DAFTAR REFERENSI}

Awadallah, E.A. \& Allam, A. (2015). A Critique of the Balanced Scorecard as a Performance Measurement Tool. International Journal of Business and Social Science, 6(7), (July), 91-99. www.ijbssnet.com. 
Bastian. (2005). Akuntansi Sektor Publik. Yogyakarta: Penerbit Erlangga.

Binden, et al. (2014). Employing the Balanced Scorecard (BSC) to Measure Performance in Higher Education-Malaysia. International Journal of Information and Communication Technology Research, 4(1), (January), 3844. http://www.esjournals.org.

Casey, W. \& Peck, W. (2004). A Balanced View of Balanced Scorecard. Executive Leadership Group. The Leadership Lighthouse Series.

Ciptani, M.K. (2000). Balanced Scorecard Sebagai Pengukuran Masa Depan: Suatu Pengantar. Fakultas Ekonomi Universitas Kristen Petra Surabaya, (Mei), 21-35. http://puslit.petra.ac.id/journals/accounting/.

Dilly. (2010). Balanced Scorecard. Bandung: Rosda.

Drucker, P. (1964). Controls, Control and Management. (in) Bonini, C., Jaedicke, R., \& Wagner, H. (Eds), Management Controls: New Directions in Basic Re-search. New York: McGraw Hill Book Company. 286-296.

Fitriah. (2010). Penerapan Balanced Scorecard sebagai Alat Ukur Kinerja PT. Triduta Solusindo Computama. Skripsi. Universitas Bhayangkara, Surabaya.

Giannopoulos, G., Holt, A., Khansalar, E., \& Cleanthous, S. (2013). The Use of Balance Scorecard in Small Companies. International Journal of Business and Management, 8(14). Canadian Center of Science and Education.

Hanuma \& Kiswara. (2011). Analisis Balance Scorecard sebagai Alat Pengukur Kinerja Perusahaan. Jurnal Ekonomi. Universitas Diponegoro.

Himawan, F.A. \& Juarsah. (2005). Balanced Scorecard sebagai Alat Pengukuran Kinerja Manajemen (Studi Kasus PT. Makro Indonesia Cabang Pasar Rebo, Jakarta). Jurnal ESENSI, 8(1).

Irsutami \& Ramadhiah. (2011). Pengembangan Pengukuran Kinerja dengan Pende-katan Balance Scorecard (Studi Kasus Politeknik Negeri Batam). Jurnal Penelitian Politeknik Negeri Batam, 13-14.

Kairu, E.W. et al. (2013). Effects of Balanced Scorecard on Performance of Firms in the Service Sector. European Journal of Business and Management, 5(9), 81-88. www.iiste.org.

Khatoon, S. \& Farooq, A. (2014). Balanced Scorecard to Measure Organizational Performance: A Case Based Study. The International Journal of Business \& Management, 2(9), (September), 106-113.

Kaplan, R. \& Norton, D.P. (2000). Balanced Scorecard Menerapkan Strategi Menjadi Aksi. Jakarta: Penerbit Erlangga.

Mulyadi. (2001). Balanced Scorecard. Yogyakarta: Salemba Empat.

McNair, C.J., Lynch, R. \& Cross, K. (1990). Do Financial and Non-financial Measures Have to Agree? Management Accounting, 72(5), 28-36.

Moeheriono. (2009). Pengukuran Kinerja Berbasis Kompetensi. Jakarta: Ghalia Indonesia. 
Novira. (2010). Balanced Scorecard sebagai alat Pengukur Kinerja Pada PT. Bestindo Intiselaras. Semarang: Universitas Negeri Semarang.

Poureisa, Arman et al. (2013). Balanced Scorecard: A New Tool for Performance Evaluation. Interdisciplinary Journal of Contemporary Research in Business (IJCRB), 5(1), (May), 974-978.

Singgih, M.L. et al. Pengukuran dan Analisa Kinerja dengan Metode Balanced Scorecard di PT. "X." Jurnal Teknik Industri, 3(2), (Desember), 48-56. Universitas Kristen Petra http://puslit.petra.ac.id/ journals/industrial.

Sinha, A. (2006). Balance Scorecard: A Strategic Management Tool. University Journal of Commerce, 11(March), 71-81.

Sipayung, F. (2009). Balanced Scorecard: Pengukuran Kinerja Perusahaan dan Sistem Manajemen Strategi. Jurnal Manajemen Bisnis, 2(1), (Januari), 7-14.

Sumarsan, T. (2010). Sistem Pengendalian Manajemen. Semarang: PT. Indeks.

Supriyono, R.A. (2000). Sistem Pengendalian Manajemen. Jakarta: BPFE.

Wirawan. (2009). Evaluasi Kinerja Sumber Daya Manusia. Yogyakarta: Salemba Empat.

Yin, R.K. (2009). Studi Kasus: Desain dan Metode. Jakarta: Rajawali Pers.

Zizlavsky, O. (2014). The Balanced Scorecard: Innovative Performance Measurement and Management Control System. J. Technol. Manag. Innov., 9(3), 210222. 